\title{
Research on the Internet-based Teaching Mode of Business English Translation
}

\author{
Liaoliao ZHANG \\ Wuhan Huaxia University of Technology, Wuhan, 430223, China \\ email: 164073893@qq.com
}

Key words: The Internet; Business English Translation; Teaching Mode

\begin{abstract}
Driven by the Internet era, the reform and innovation of foreign language education is bound to combine with network information technology. Accordingly, the cultivation of foreign language talents, especially talents in business English translation, is promoted by network information technology. Thus, based on the connotation and features of business English translation, this paper firstly generalizes its current teaching situation in college. And then, relied on the great advantages of network information technology, it explores a network-aided way to reform the teaching mode of business English translation from the aspects of teaching content, teaching methods and platform construction.
\end{abstract}

\section{Introduction}

According to the CNNIC's 41st report released in January, 2018, the number of Internet users by December, 2017 reaches up to 772 million while that of phone users amounts to 753 million. Besides, as shown in the survey published by China Youth Daily, the proportion of smartphone users in colleges reaches up to 99\%. [1] That means, the traditional platform based on personal computer cannot meet people's needs surfing on the Internet at anytime and anywhere while smartphone can play the role of mobile pocket computer. It is obvious that the human society has entered the information age. [2] Driven by the Internet era, education is accordingly experiencing a great reform based on network technology. According to The Ten-year Development Strategies of Education Informationization from 2011 to 2020 released by Education Ministry, hiher education will be deeply integrated with network information technology, which will modernize teaching content and teaching methods, innovate talent training mode and finally promote the all-round improvement of higher education.[3] Obviously, the network information technology in the Internet era will greatly promote the continuous update of teaching content, the improvement of teaching methods, the innovation of teaching mode and the systematic and diversified development of education evaluation system.[4] Therefore, to line up with the Internet era and to train modernized foreign language talents for the society, attention should be directed to the reform and innovation of foreign language talents training, foreign language course construction and foreign language teaching.

\section{Features of Business English Translation Courses}

Business English translation, as a variant of translation in specific context, combines the features of translation and business. Compared to other translation courses, it is characterized by its involvement of business. Its features are vividly shown in its translated texts.

\section{A. Lexical style}

The translated texts of business English translation cover a lot of technical terms, acronyms, and semi-professional vocabularies with specific business meanings. Therefore, it should be precise and professional.

\section{B. Syntactic style}

The sentences in the translated texts of business English translation are compact, rigorous, and 
full of rich information. Long sentences and passive sentences are commonly used. Thus, translators should take the accuracy, timeliness, and logic of translation into account.

\section{Textual style}

The translated texts of business English translation are complete, concise, specific, accurate, clear, polite and considerate. Thus, translation versions should be accurate, concise and appropriate, lining up with the business features like preciseness and normalization.

\section{The Current Teaching Status of Business English Translation}

The increasingly frequent foreign business activities have triggered greater demand for applied talents of business translation who are quite familiar with the reginal economic and trade development. Moreover, colleges and universities are expected to cultivate applied talents of business translation to serve local economic and trade cooperation, construction and trade, logistics, processing and production, etc.. [5] In response to the market demand, business English major in colleges and universities has set business English translation as the core course so that the students are able to have a good command of international business, to be familiar with translation processes, and to acquire the basic theoretical knowledge and skills of business English translation, which will lay the foundation for students to translate all types of business texts in the future. However, the development of Internet has posed challenge to the traditional translation industry. Problems have kept cropping up in the teaching practice and the course now fails to cultivate business translation talents with strong operational and application capabilities:

\section{A. Limited course duration}

The course of business English translation is compulsory for senior students in English major. It aims that students can grasp the basic knowledge and skills of translation, the basic procedures of business activities, and the basic content and characteristics of business texts. As we all know, the important indicators for measuring learning effect are adequate time and efficient learning. Nevertheless, the course of business English translation is taught for only one or two semesters. The reasons are that the majority of universities have strict restrictions on course duration and basic courses have already taken up most of the time. That means it is difficult to for a teacher to teach business English translation theories and conduct translation training simultaneously within the limited and planned course duration.

\section{B. The outdated teaching content}

Business English translation textbooks used by the business English major of Chinese universities are currently divided into business English translation and business English interpretation. Very few textbooks combine both translation and interpreting. In terms of the content, the teaching materials of business English translation can fall into three categories: The first is mainly composed of translation theory and translation exercise; the second firstly gives an overview and explanation of the language features and translation standards of business English, and then offers a detailed explanation of the specific translation techniques and methods from the aspects of the words, sentences and chapters of business texts. The third is to set up different module units according to business environment, including law, economics, trade, finance, accounting, management, securities, marketing, tourism and so on. Although the business English translation textbooks adopted by universities are rich in content and diverse in form, the content and the exercise of the textbooks are outdated and rigid. To make matters even worse, the update speed of the textbooks is far behind than that of the real-time business information. Therefore, these textbooks cannot meet the actual needs of students and society.

\section{Monotonous teaching environment}

The teaching environment is not just limited to classrooms. It has extended to classrooms in community. In traditional teacher-dominated classes, students always receive knowledge of 
translation and business passively, so it's difficult to achieve the ideal classroom scene of intense interactions between teachers and students, or among students. Besides, students' interest in learning is also declined and the ideal learning state can not be reached. Under such teaching environment, business translation training features lack of information amount, intuitiveness and efficiency. Off-campus internships for business language translation are even more difficult, because very few companies are willing to provide internships for students majoring in translation. Even if they do, 2 to 3 persons at one time would be their limit. What's more, there are many restrictions on students in the organizations but few contents of practice, which virtually limits or wastes opportunities for students to do translation practice. Therefore, the most urgent problem now is to closely combine the translation theory learned by students with their translation practice and to enable these students to truly serve the community.

\section{Outmoded teaching method}

Most colleges and universities still follow the "spoon-feeding" teaching method that teachers speak while students only listen to, which has certain limitations, including the still existing situation that the whole class is controlled by one textbook and a piece of chalk. Most teachers are able to search course-related resources online and adopt case-based or heuristic teaching methods to improve students' translation skills during the teaching processes. However, the classroom activity is not rich enough, the teaching design is relatively simple and the old and new teaching contents are not closely converged. Although a small number of teachers apply multimedia to teaching, the use of modern multimedia and network technology is still insufficient. Furthermore, the inflexible teaching methods as well as dull class atmosphere are incapable of bringing students to learn and perceive in real life. This kind of passive-acceptance learning, which emphasizes memory rather than practice, restrains students' divergence of creative thinking and improvement of translation skills.

\section{Internet-based Teaching Strategies of Business English Translation}

The characteristics of the Internet have brought significant changes to the language service industry, creating a fresh ecosphere of Internet translation and putting forward new requirements for the traditional translation teaching. That is the business English translation teaching should make full use of the network platform and information technology, integrating actual translation work with classroom teaching and building real translation environment in and out of classroom. By doing so, students are able to learn business English translation well in constant practice.

\section{A. Resourceful teaching content}

The "Internet" has opened education. The rapid development of information technology, the widespread popularity of school network together with the high efficiency and convenience of the Internet make it possible that education can keep pace with the times and instructional information features authenticity and immediacy. The business English translation teaching must take full advantage of the network data transmission method for more timely and authentic business text materials in various fields, such as science and technology, economy and trade, law, agriculture and art, so as to make up for the information lag and content limitations of texts. In addition, the application of computer-aided translation tools and parallel corpora can help expand the teaching contents for business English translation courses, which will not only assist students to bound up knowledge learned in class with actual work, achieving the development of individuals, of the community and the local economy, but also help to improve students' ability of information technology application and translation technology operation.

\section{B. Innovation of teaching methods}

Compared with the traditional teaching methods in which lessons can only be taught and learned at one fixed time and place, the learning style of the Internet era is more flexible. The Internet enables students to study without time and space limitation. They are able to learn anytime 
and anywhere so long as they have a computer or a mobile phone, which leads to considerable advancements in use of time, and creates wider space for students to communicate and share. In addition, in the personalized and diversified learning system constructed by the Internet, students can determine the genres and contents of business translation in accordance with their different levels, preferences, and needs of learning. The Internet era gives impetus to changes of learning methods, which also affects the teaching attitudes and skills of educators and brings about their changes. In the learning process of the Internet model, participant, information generator and other multiple roles are added to teachers' roles from controller, evaluator, organizer, and supervisor in traditional teaching. Besides, the relationship between teachers and students is more equal. Teachers, who has worked and collaborated with students, are willing to discuss and study together with them to make progress.

\section{Construction of teaching platform}

An Internet-based flipped teaching system of College Business English Translation should be established, with communication and computer network system as its platform, and computer monitoring system and mobile internet application platform as its core. The system provides students with a platform of information exchange and sharing to improve their capability of independent learning efficiency. The development of information and network technology incubates sites of crowdsourced translation, which has revolutionized the traditional translation industry. The crowdsourced translation model offers a platform for both the suppliers and the buyers - translation tasks are published through the Internet to seek translators who are voluntary to fulfill the task. Many industries have witnessed the success of crowdsourced translation, from Facebook, Global Voice, TED, Kiva in abroad to YeeYan, YeeCloud, Gukoo, Polly and other crowdsourced translation sites at home. However, it is barely valued and utilized in translation teaching of colleges and lacks relevant researches in this field. The opportunities of practice in this field still need to be explored. The practice teaching of Business English Translation should make full use of the crowdsourced translation sites as a platform for students to carry out translation practice. By participating in crowdsourced translation projects, students are able to gain direct translation experience in a real translation environment, and to improve translation skills and capabilities of social services.

\section{Conclusion}

This practice-oriented study aims to solve the practical problems in the teaching of Business English Translation and explore a new model which integrates theory and practice. With the network information technology as a tool, it discusses the reform and innovation of teaching contents, model, methods of practice and assessment in the teaching of Business English Translation in a scientific manner. This research suggests that, in order to develop with the time, it is necessary to cultivate students' abilities of language application, translation skills of Business English, application of modern translation technology, and spirits of collaboration. With the aid of modern information technology, a student-centered construction concept which aims at cultivating students' practice skills should be framed to promote reform of teaching.

\section{References}

[1] Developments in English for Specific Purposes: A Multi-Disciplinary Approach. Dudley-Evans T,St John MJ. . 1998

[2] Business English. Bargiela-Chiappini F,Zhang Z C. The Handbook of English for Specific Purposes . 2013

[3] Language test construction and evaluation. Alderson JC,Clapham C,Wall D. . 1995

[4] A corpus-based evaluation of metaphors in a business English textbook[J] . Hanna Skorczynska 
Sznajder. English for Specific Purposes . 2009 (1)

[5] Reconceptualising English for Business Communication. Bhatia V K. Second National Conference on Business Linguistics . 2015 